\title{
The effect of discards and survival rate on the Maximum Sustainable Yield estimation based on landings or catches maximisation: Application to the nephrops fishery in the Bay of Biscay
}

\author{
Jordi Guillen ${ }^{\mathrm{a}, \mathrm{b},{ }^{*}, \text { Claire Macher }}{ }^{\mathrm{a},}$, Mathieu Merzéréaud ${ }^{\mathrm{a}}$, Spyros Fifas ${ }^{\mathrm{c}}$, Olivier Guyader ${ }^{\mathrm{a}}$ \\ a IFREMER, UMR AMURE, Unité d'Economie Maritime, BP 70, F-29280 Plouzané Cedex, France \\ ${ }^{b}$ Institut de Ciències del Mar - CSIC, 08003 Barcelona, Spain \\ c IFREMER, Unité Sciences et Technologies Halieutiques, BP 70, F-29280 Plouzané Cedex, France \\ *: Corresponding author : Jordi Guillen, email address : jordiguillen@hotmail.com
}

\begin{abstract}
:
MSY objectives are being adopted as major fisheries management targets worldwide. However, in fisheries where discards account for an important share of the catches, the yield, effort, and biomass at MSY can be significantly different when accounting or not for discards and thus when, basing the yield estimations on landings or catches. Also whether accounting for a certain survival rate, of discards can lead to different MSY targets estimates. Hence, both decisions have important, implications on catch and effort reduction recommendations, and consequently on the quota, calculations for fisheries managed by quotas. Results from the Bay of Biscay nephrops fishery confirm, that the optimal exploitation level can vary significantly when optimising for catches or landings, and, by assuming a certain survival rate of the discards. By doing this, the present study also allows to, explore the basis to clarify the definition of MSY in fisheries where discarding takes place.
\end{abstract}

\section{Highlights}

The presence of discards affects the MSY estimation. MSY levels change when basing the yield estimations on landings or catches. Effort level is higher when maximising catches than landings.

- Higher survival rates of discards lead to higher effort and quotas at MSY.

Keywords: Maximum Sustainable Yield (MSY) ; Discards ; Nephrops ; Survival rate 


\section{Introduction}

MSY is widely interpreted as the maximum long term average catch that can that can be achieved under prevailing conditions, including both the state of the ecosystem and size selectivity of the fishery [1]. The target of fisheries operating at MSY meets both biological sustainability and production maximisation objectives [2-3]. Achieving MSY has become a key issue for fisheries policy as agreed at the 2002 Johannesburg"s World Summit that stated to achieve the MSY objective for all stocks in 2015 [4], which was re-iterated at the Rio+20 United Nations Conference of Sustainable Development in 2012 [5]. As a result, MSY has been adopted as a fisheries management objective by many countries and international management bodies. This has also resulted in the European Commission proposal to set MSY as the main objective in the reform of the European Union"s Common Fisheries Policy (CFP).

The extended practice of discarding has been identified as one of the reasons for the failure of the past CFP [6-8]. Discarding has prevented several EU fish stock from recovering, despite the low landing quotas [6-8]. Discards occur for several reasons, mainly because of low demand for non-target species, and because of minimum landing size regulations and highgrading for target species $[7,9]$. Latest worldwide estimates report about 30 million tonnes of discards, accounting for $23 \%$ of the global catches [10], where catches are the sum of landings and discards. However, discards are highly variable depending on fisheries, species, and fishing gears [11]. Indeed, discards can reach $80 \%$ of the catches in some fisheries. Discarding is a common practice in demersal fisheries such as the nephrops fishery in the Bay of Biscay [1214].

The impact of discards in a fishery depends however on the survival rate that is linked to the species and the fishing gear [15]. The survival rate of discards is generally low for fishes and can reach $0 \%$ of the discards for some of them [15-17]. The survival rate is higher for crustacean such as nephrops. The survival rate for the discarded nephrops has been assessed around 30\% [18-19], resulting in a mortality rate of around $70 \%$, which has been discussed in several papers afterwards [20-23]. Recent experimentations show that this survival rate could be higher because of improvements in the sorting process [24].

Many fisheries worldwide are managed by quota systems, either catch or landing quotas. Quota levels are often set so that the stock size tends towards the biomass level that produces MSY (B $\left.B_{\text {MSY }}\right)$. For example, the EU"s CFP has various measures to manage fish stocks, where landing quotas or total allowable catches (TACs) play a key role. However, in fisheries where discards account for an important share of the catches, MSY estimations ( $B_{M S Y}, E_{M S Y}$ and mortality levels, and consequently the quota level) can be significantly different when accounting or not for discards and thus basing the yield calculations on catches or on landings maximisation. Similarly, if a fraction of the discards survives, this can also lead to significant differences in these optimal estimates. Consequently, both issues, choosing between landings or catches maximization and accounting or not for survival of discards, have important implications when determining the yields that can be harvested annually from the stocks. They also have important implications on quota calculations (on fisheries managed by quotas), and effort reduction recommendations towards MSY. In the new EU"s CFP a landings obligation (discard ban) is implemented gradually, this way landings and catches will match and thus these issues will be mitigated in some fisheries. 
This paper explores the impact on MSY estimates of maximising catches or landings, and the effect of the survival rate of discards. Analyses are applied to the Bay of Biscay nephrops (Norway lobster, Nephrops norvegicus) fishery, a demersal mixed fishery that is characterized by high levels of discards [12-14]. Therefore, the analyses of this nephrops fishery allow to obtain important insights of the effects that discards and their survival have on the MSY estimation and quota determination in fisheries where discarding occurs. In particular, the focus on a species (nephrops) that shows a certain discard survival and the sensibility analysis of the results to the discard survival (section 3.2) let to extent the results of this study to species with lower (e.g. fishes) and higher (e.g. crustaceans such as crabs and lobsters) discard survival. This allows to set the basis to clarify the definition of MSY in fisheries where discarding takes place.

\section{Materials and Methods}

\subsection{Case Study}

Nephrops in the Bay of Biscay is fished by bottom trawlers (Figure 1). In 2009, 197 bottom trawlers caught more than one ton of alive nephrops in the Bay of Biscay. Among them, 115 bottom trawlers target nephrops throughout the year and depend on nephrops for more than $40 \%$ of their gross revenue while 82 trawlers target nephrops only during a certain period of the year. The fishery is managed by TACs and quotas and by a licence system. Bottom trawlers use poorly selective gears which lead to high amounts of undersized catches of target species and to by-catches of other species [25].

In $2009,58 \%$ of nephrops catches in number (38\% in weight) were discarded in the Bay of Biscay [13]. Those discards were mainly composed of the smallest individuals that were below the minimum landing size (9 $\mathrm{cm}$ for nephrops) [13]. Discarding has negative impacts on stock renewal as $70 \%$ of the nephrops discards die [18-19].

\subsection{Simulation model}

MSY estimations for the nephrops fishery in the Bay of Biscay have been performed using the biological component of the bio-economic model IAM (Impact Assessment Model for fisheries management) [12, 25-27]. The model is developed in R/C++ languages [28-29]. It is an integrated model coupling the biological dynamics of fish stocks with the economic dynamics to perform impact assessments taking into account the biological impacts and the economic impacts for fleets. This model assesses impacts in the short, medium and long term, transition phases, and impact distributions between different fleets. It is age structured, spatially aggregated and has an annual time step. The model calculates at each time step fishing mortality, spawning biomass, biomass, total catches, landings and discards accounting for survival of discards, landings by fleet, fleet and individual economic performances, the total number of vessels by fleet, employment and crew salaries. The model can assess the impacts of various management scenarios such as fishing gear selectivity improvement, decrease in time fishing per vessel, decrease in the number of vessels, and quota constraints. The model is used in Macher et al. [12] and Raveau et al. [25] to assess the impact of selectivity improvements in the nephrops fishery of the Bay of Biscay. It is also used within STECF to assess several scenarios of achieving MSY in the sole fishery of the Bay of Biscay [30], and in Guillen et al. [27] to estimate the MSY and MEY in multispecies and multi-fleet fisheries. Main equations of the IAM model relevant to the current study are described below for the nephrops case study. The IAM bio-economic 
model allows to account for multi-species and multi-fleets, but in this study it is only modelled one species (nephrops) and one fleet (bottom trawlers).

The IAM model assumes proportionality between the rate that individuals are captured by the fishing gear by age group i $\left(F C_{i}\right)$ and nominal fishing effort $(E)$ :

$$
F c_{i}=m E \times E \times q_{i} \quad \text { (equation 1) }
$$

where $q_{i}$ is the catchability by age-class (i) for a given fleet. $m$ is a multiplier of the nominal effort $E$ used for simulations of scenarios.

The fishing mortality corresponding to removals (landings and dead discards), denoted $F r$, is given by:

$$
F r_{i}=F c_{i} \times K \quad \text { (equation 2) }
$$

where $K$ is the corrected factor of the fishing mortality that accounts for the survival of discards, modelled following Mesnil [31], such that:

$$
\left.K_{i}=1-\left(s r_{i} \times d_{i}\right) \quad \text { (equation } 3\right)
$$

where $s r$ is the survival rate and $d$ is the percentage discarded in number by ageclass, as seen before.

Survival of nephrops is calculated following Beverton and Holt as:

$$
N_{i+1, t+1}=N_{i, t} \times e^{-Z_{i, t}} \quad \text { (equation 4) }
$$

where $N$ is the total number of individuals and $Z$ is the total mortality (natural and removal fishing mortality).

Catches in number per age group $\left(C n_{i}\right)$, are related to fishing mortality, by the Baranov equation:

$$
C n_{i}=F_{i} \times N_{i} \times \frac{\left(1-e^{-Z_{i}}\right)}{Z_{i}} \quad \text { (equation 5) }
$$

Discards in number $(D n)$, by age-class are estimated in the model by:

$$
D n_{i}=C n_{i} \times d_{i} \quad \text { (equation 6) }
$$

where $d$ is the percentage discarded in number by age-class. In this study it is assumed a constant discarding behaviour based on historical data, the percentage of discards by age is considered constant over time (each year).

Landings in number $(L n)$ are obtained by the difference between Catches in number and Discards in number, in the model are given by:

$$
L n_{i}=C n_{i}-D n_{i} \quad \text { (equation 7) }
$$


Discards in weight $(D)$ and Landings in weight $(L)$, are estimated in the model by:

$$
\begin{aligned}
& D_{i}=w_{D i} \times D n_{i} \quad \text { (equation 8) } \\
& L_{i}=w_{L i} \times L n_{i} \quad \text { (equation 9) }
\end{aligned}
$$

Where $w_{D}$ is the mean weight of discards, and $w_{L}$ is the mean weight of landings.

Simulations on catch and landing evolutions for the nephrops fishery according to a range of effort multipliers were performed with the IAM model. MSY estimates (maximum catches and landings) and the corresponding effort and biomass at equilibrium were obtained by optimization with the IAM model.

\subsection{Data}

The IAM model was parameterized with the outputs from the stock assessments performed by ICES in 2012 (i.e. fishing mortality, stock numbers at age, mean weight at age, discards at age) for the stock of nephrops in the Bay of Biscay [32]. Hockeystick stock-recruitment relationship was adjusted based on 1987-2011 data ${ }^{1}$.

Table 1 presents the main data on the nephrops fishery: total biomass, fishing mortality, nephrops catches, landings and discards by the bottom trawl fleet in 2011; table 2 details the main data by age-class.

\subsection{Scenarios analysed}

The nephrops catches, landings, discards and fishing effort multipliers at MSY are estimated under four scenarios (Table 3 ) according to the variable which is maximized (landings or catches) and the survival rate considered (0 or $30 \%$ following Guéguen and Charuau [18] and Charuau et al. [19]).

\section{Results}

Main results are presented on table 4. Section 3.1 "landings or catches maximisation" compares scenarios $A$ and $B$, and scenarios $C$ and D. Section 3.2 "Accounting for discard survival" compares scenarios $A$ and $C$, and scenarios $B$ and $D$ and provides a sensitivity analyses of landings to effort and survival rate.

Results show that the optimal exploitation level can vary significantly when optimizing for catches or landings, and also whether assuming a certain survival of the discards or

\footnotetext{
${ }^{1}$ Hockey stick stock-recruitment relationships have been chosen because they offer a shape closer to the production functions usually used in more theoretically economic models and more realistic when considering impact of high effort levels on recruitment. It should be noted that the inflexion point parameters have been arbitrarily chosen from the nephrops stock assessment data because historic recruitments have proven to be robust and there is no perception of inflexion points on the data. The optimal reference points for this nephrops fishery have shown to be independent of the inflexion points in the stock-recruitment relationships.
} 
not. In fact, optimal nephrops stock levels ( $\mathrm{B}_{\mathrm{MSY}}$ ) vary from 16,239 to 28,478 tonnes and $E_{M S Y}$ from 0.57 to 1.39 , potentially resulting in a $43 \%$ decrease on the current effort to a $39 \%$ increase to maximize the yield (landings or catch respectively) considering survival of discards or not.

Table 4 shows that maximum yield estimations for the nephrops fishery in the Bay of Biscay would result in 5,641 tonnes of catches (or 4,135 tonnes of landings) when aiming at maximising catches assuming no survival of discards; or 5,480 tonnes of catches (or 4,334 tonnes of landings) when aiming at maximising landings assuming no survival of discards. When a $30 \%$ survival rate of discards is considered in the estimation, yields can increase up to 6,464 tonnes of catches (or 4,266 tonnes of landings) when aiming at maximising catches; or 6,131 tonnes of catches (or 4,792 tonnes of landings) when aiming at maximising landings. These yield estimations would be equal to the quotas at equilibrium if the fishery was optimally managed, and there were no inter-annual variations in the recruitment ${ }^{2}$.

\subsection{Landings or catches maximisation}

Figure 2a compares the curves of sustainable nephrops landings and catches as a function of effort assuming no survival of discards in equilibrium. Catches are either retained or die when discarded in this case; in both cases yields are compared. Figure $2 \mathrm{~b}$ compares the maximum sustainable nephrops landings and catches as a function of effort assuming a $30 \%$ survival rate on discards ${ }^{3}$.

Both figures show that the effort level that maximizes landings is lower than the effort that maximizes catches in equilibrium. Lower effort levels correspond to a larger nephrops stock size. The difference between catches and landings in both figures is equal to the discards. Discards increase disproportionally high when effort increases because the average weight of nephrops in the stock, and consequently in the catches, decreases.

When assuming no discards survival, the $E_{M S Y}$ is reduced from 0.86 of the current effort when optimising catches, to 0.57 when optimising landings. Thus, current effort needs to be reduced by $14 \%$ to $43 \%$ to maximize catches or landings yields, respectively. Corresponding value of MSY based on landings is 34\% lower than MSY value based on total catches. When assuming survival of the discards, the $E_{M S Y}$ decreases from 1.56 to 0.66 of the current effort according to the variable to be maximized, catches or landings respectively. The MSY calculated on landings is $58 \%$ lower than the MSY calculated on catches assuming discards" survival. Maximizing catches instead of landings can lead to an increase of discards. In this case, discards increase by $31 \%$ compared to maximising landings with no discard survival and by $64 \%$ when discard survival is assumed.

The $\mathrm{B}_{\mathrm{MSY}}$ is $37 \%$ larger when optimizing landings instead of catches and assuming no survival of discards. It is $71 \%$ larger when optimizing for landings compared to optimizing for catches when assuming a 30\% survival rate for discards. The average weight of nephrops biomass is $44 \%$ larger when maximising landings than when

\footnotetext{
${ }^{2}$ Under normal conditions, of inter-annual variations in recruitment, the annual quotas are unlikely to be equal to the MSY yield estimations, because the annual TAC will be roughly equal to $\mathrm{F}_{\mathrm{MSY}} * \mathrm{~B}$ and biomass (B) will not be constant from one year to the next due to the variation in recruitment. Therefore, quotas will vary annually around the MSY estimations.

${ }^{3}$ The odd kinks in the yield versus effort curves (figures $2 a, 2 b, 3 a$ and $3 b$ ) are due to the kink in the assumed hockey-stick shape of the stock-recruitment relationship curve.
} 
maximising catches and accounting for discard survival. While the average weight of nephrops landings is $28 \%$ larger when maximising landings than catches and accounting for discard survival, it is a $15 \%$ larger when it is assumed no discard survival.

\subsection{Accounting for discard survival}

Figure 3a compares the nephrops landings as a function of effort both with and without survival of discards; figure $3 \mathrm{~b}$ compares the nephrops catches, also with and without survival of discards.

Figures $3 \mathrm{a}$ and $3 \mathrm{~b}$ illustrate the effect of discards in the assessment models, when accounting for a certain survival rate ( $30 \%$ in the case of nephrops) of discards.

When accounting for a $30 \%$ survival rate of discards, $E_{M S Y}$ is higher than $E_{M S Y}$ when assuming no survival. Our results show that for Bay of Biscay nephrops, effort that maximizes the catches is $62 \%$ higher when assuming survival of discards than when assuming no survival of discards. Effort that maximizes landings is $19 \%$ higher when assuming survival of discards than when assuming no survival of discards. This leads to optimal target yields (quotas) that are higher when assuming the survival of discards. Optimal catches are a $15 \%$ higher and optimal landings are $11 \%$ higher when assuming survival of discards. As a consequence, the $\mathrm{B}_{\mathrm{MSY}}$ accounting for discards survival is lower than the $B_{\text {MSY }}$ when assuming no survival $(22 \%$ and $2 \%$ lower for catches and landings respectively). This also results in the average weight of nephrops biomass being $16 \%$ and $3 \%$ lower and the average weight of nephrops landings being $14 \%$ and $3 \%$ lower when accounting for discard survival when maximising catches and landings respectively.

As shown on Figure 4, for species with low survival rate of discards, the $E_{M S Y}$ is obtained at lower fishing mortality $\left(\mathrm{F}_{\mathrm{MSY}}\right)$ and thus lower fishing effort. This leads to a higher biomass at sea.

Furthermore, landings at MSY increase slightly with increasing survival rate and the percentage of discards from the total catches increases (because of a lower average size of the catches) when the fishing effort and survival rate increases.

\section{Discussion}

The important difference in the effort needed to maximize catches or landings occurs because often discards are not proportional to landings" weight, but to the distribution of the catches by age-class. Nephrops discards on the Bay of Biscay fishery involve the smaller individuals that are under the Minimum Landing Size, as it happens in many fisheries. Therefore, the discards evolution (and thereby the difference between catches and landings) is explained because when fishing pressure increases the average size of the catch declines and discards increase when assuming a constant rate of discards by age group. The discards' increase observed when the average size of catches decreases is linked to minimum landing size regulations. Constraints of the processing industry for smaller individuals and a lower demand for small individuals can also be other reasons for discarding $[7,9]$.

MSY is widely interpreted as the maximum long term average catch that can that can be achieved under prevailing conditions, including both the state of the ecosystem and 
size selectivity of the fishery [1]. Therefore, size at age and weight at age are assumed to remain stable, and consequently not to be influenced by the fishing activity, as in this study. However, long term high levels of fishing pressure and size-based discards could lead to evolutionary responses [33-35]. Induced phenotypic adaptation to fisheries could lead to a reduction in the long-term yields. However, there is high uncertainty on the level of these potential changes and when they will occur. Moreover, these potential changes due to phenotypic adaptation should not have a relevant impact on the significant differences between yield estimations based on landings or catches.

Accounting for a certain survival rate of the stock also leads to changes in the target biomass, effort and yield. In fact, when it is considered that $30 \%$ of the discards survive in the case of nephrops, target yields (landings) increase by $11 \%$ compared to the situation where no survival is assumed. At the same time, when assuming discard survival, $B_{M S Y}$ is $22 \%$ smaller. Therefore, improvements in the sorting of discards that could lead to increases in their survival would allow higher yields from the fishery.

Nephrops often has a higher survival rate for discards compared to other species, especially fish [15-17], but lower compared to other crustaceans such as crabs or lobsters [36-38]. This implies that the detrimental effects of discards are even larger for most fish species, while lower for some other crustaceans (i.e. crabs and lobsters) than the ones shown in this paper for nephrops. So, for species with high survival rate of discards, it is beneficial to discard small size individuals to capture them at a later stage with a higher size; while, for species with low or null survival rate of discards, it is not going to be possible to capture them later. However, most of the discards are due to the catch of undersized individuals that need to be discarded because of the minimum landing size regulation. Even if a regulation that encourages discards of undersized individuals may not seem beneficial for species with a low or null survival rate of discards, such a regulation could be beneficial because it may have a deterrence effect to avoid the capture of large amounts of undersized individuals. So, it could be possible that if the minimum landing size regulation was not in place, more undersized individuals would be captured, leading to a lower level of landings.

Normally, in fisheries, different species are caught jointly with the target species, and some of these by-catch is discarded. Hence, in order to avoid discards, together with reducing fishing effort [27], it is important to improve selectivity in the fisheries, for both target and by-catch species. Indeed, improving selectivity, in particular reducing retention by the gear of the smallest individuals, results in medium to long term higher yields per unit of fishing effort and in greater catch values [14, 25, 39-43]. However, it seems that the adoption of selective devices by fishermen is hampered because of the uncertainty of potential future gains, but also because individual fishermen suffer the loss of catch due to the escapement of individuals with commercial sizes, while benefits are gathered by the collectivity [25]. So individual fishermen have incentives not to adopt selective devices.

It should be considered that because the nephrops stock is currently overfished [27], a transition period will be needed to let the spawning biomass grow to reach the $B_{M S Y}$ level. Because the current stock biomass is less than $B_{M S Y}$, during this transition period the TACs will need to be reduced to allow the stock to grow. Therefore, when the stocks are at low levels, to move towards MSY will require a period of reduced catches, aiming to recover this investment with higher quotas once the stock is at $B_{M S Y}$. If the stock was underexploited, there would be the need to set the quotas above MSY levels so that the stock biomass can shrink to $B_{M S Y}$. 
The term "overfished" is commonly used to refer to a low level of stock abundance [3]. A stock is often considered "overfished" when its stock abundance is lower than the Biomass at Maximum Sustainable Yield ( $\left.B_{\mathrm{MSY}}\right)$ [44-45]. Therefore, a fish stock being overexploited implies that the stock is producing less in biologic terms than what could be obtained if it was optimally managed (i.e. with biomass at sea at $\mathrm{B}_{\mathrm{MSY}}$ ). However, the assessment of a stock could change from overexploited to underexploited (or vice versa) depending on the assumption of the survival rate of discards and whether maximising landings or catches. As can be seen in this analysis, $\mathrm{B}_{\mathrm{MSY}}$ at sea when maximising catches, ranges from 20,852 tonnes when no survival is assumed to 16,239 tonnes when estimating survival, compared to the 16,665 tonnes of the current stock. In this context, stock status assessments are important because they can be decisive regarding whether a management plan needs to be developed, and it will define the effort and time needed to reach the management target (often MSY). It should be noted that these effects would be mitigated in fisheries with a lower proportion of discards, consequently, more similar optimal yields and effort levels are to be expected in the estimation of maximum catches and landings.

Results obtained set the basis to discuss the definition of MSY in fisheries where discards takes place. ICES [1] states that MSY is widely interpreted as the maximum long term average catch that can be achieved under prevailing conditions, including both the state of the ecosystem and size selectivity of the fishery. In addition, ICES [1] asserts that the determination of Yield between catches and landings in MSY depends on the management objective: "the choice of Yield $(Y)$ as catches or landings is a matter for policy: if Yield is considered to be that which is removed from the stock MSY (FMSY) should be based on maximising catch; if Yield is considered to be the utilised component from the stock, the amount contributing to economic and social benefit, then Yield should be taken as landings and FMSY calculated accordingly to maximise landings". We believe that interpreting MSY as the Maximum Sustainable Total Catches (including discards of commercially valueless and illegal individuals) is awkward; instead Yield should be clearly related to landings. From the societal point of view, the value to be maximized is the amount of food that the fishery provides or the rent from the fishery which means a maximization of the difference between gross revenue and costs (equivalent to the Maximum Economic Yield, MEY). Therefore, it is clear that not catches, but landings should be maximized, which are the part of the catches used by the society; there is no sense to maximize harvest if a part of the catch is discarded afterwards. This also explains that in the potential presence of discards, it would be better to base TACs and quotas on the fish removed from the stock (catches) and not on landings, because discards may vary overtime, and consequently landings may not be proportional to catches. However, catches and the potential survival of discards can be proven difficult to monitor.

By including economic considerations (i.e. revenues from the landings and fishing costs), the optimal exploitation level that maximises the rent (MEY) would be characterized by a lower fishing effort and a larger optimal biomass than at MSY. Fishing at MEY would therefore lead to lower fishing costs and lower discards compared to MSY [27, 46-48]. These effects could be accentuated when considering that prices depend on size [49], since the average length of specimen would increase by having a higher biomass and a lower fishing effort $[10,23]$.

\section{Conclusions}

In this paper, based on the nephrops Bay of Biscay fishery, it is analysed the sensitivity of MSY reference points ( $B_{M S Y}, E_{M S Y}$ and yields) to the optimized variable -landings or 
catches- and to the survival rate of discards. Results are relevant for any fishery where discards take place. The detrimental effects of discards are larger for species with lower survival rate (i.e. fishes), while effects are lower for species with higher survival rate (i.e. crabs and lobsters). It is concluded from this analysis that (i) differences can be important and can impact the recommendations of quotas and effort reductions to reach MSY and (ii) that landings (and not catches) should be maximized, as part of the catches that contribute to the welfare of the society, either directly by their consumption or through the value chain.

\section{Acknowledgments}

This work has been carried out with the support of the French Research Agency, ANR, (Agence National pour la Recherche) through the research program entitled Adhoc and with the support of the European FP 7 project Benthic Ecosystem Fisheries Impact Study (BENTHIS).

\section{References}

[1] ICES. Report of the workshop on implementing the ICES Fmsy framework, 22-26 March 2010, Copenhagen, Denmark. ICES CM 2010/ACOM:54. 83 pp. 2010.

[2] Beverton RJH, Holt SJ. On the dynamics of exploited fish populations. United Kingdom Ministry of Agriculture and Fisheries, Fishery Investigations, Series II, Volume XIX. London; 1957.

[3] Hilborn R, Stokes K. Defining overfished stocks: Have we lost the plot? Fisheries 2010; 35: 113-20.

[4] United Nations. Report of the World Summit on Sustainable Development. Johannesburg, South Africa; 2002.

[5] United Nations. The future we want. United Nations Conference on Sustainable Development. Brazil. 2012. https://rio20.un.org/sites/rio20.un.org/files/a-conf.216l1_english.pdf.pdf.

[6] Commission of the European Communities (EC). Green Paper on the Reform of the Common Fisheries Policy. Brussels, 22.4.2009, COM(2009) 163 final. 2009.

[7] Catchpole TL, Frid CLJ, Gray TS. Discards in North Sea fisheries: causes, consequences and solutions. Marine Policy 2005; 29: 421-30.

[8] Daw T, Gray T. Fisheries science and sustainability in international policy: a study of failure in the European Union"s common fisheries policy. Marine Policy 2005; 29: 18997.

[9] Pascoe S. Bycatch management and the economics of discarding. FAO Fisheries Technical Paper. No 370. Rome, FAO. 137 pp. 1997.

[10] Nellemann C, Mac Devette M, Manders T, Eickhout B, Svihus B, Prins AG, Kaltenborn BP. The environmental food crisis - the environment"s role in averting future food crises. A UNEP rapid response assessment. United Nations Environment Programme; GRID-Arendal. Available at www.grida.no. 2009.

[11] Rochet M-J, Trenkel VM. Factors for the variability of discards: assumptions and field evidence. Canadian Journal of Fisheries and Aquatic Sciences 2005; 62: 224-35.

[12] Macher C, Guyader O, Talidec C, Bertignac M. A cost-benefit analysis of improving trawl selectivity in the case of discards: The Nephrops norvegicus fishery in the Bay of Biscay. Fisheries Research 2008; 92: 76-89. 
[13] ICES. Report of the working group on the assessment of southern shelf stocks of hake, monk and megrim (WGHMM), 5 - 11 May 2010, Bilbao, Spain. ICES CM 2010/ACOM:11. 599 pp. 2010.

[14] Macher C, Boncoeur J. Optimal Selectivity and Effort Cost A Simple Bioeconomic Model with an Application to the Bay of Biscay Nephrops Fishery. Marine Resource Economics 2010; 25: 213-32.

[15] Davis MW. Key principles for understanding fish bycatch discard mortality. Canadian Journal of Fisheries and Aquatic Sciences 2002; 59: 1834-43.

[16] Hill BJ, Wassenberg TJ. Fate of discards from prawn trawlers in Torres Strait. Marine and Freshwater Research 1990; 41: 53-64.

[17] STECF. $39^{\text {th }}$ Plenary meeting report of the Scientific, Technical and Economic Committee for Fisheries. JRC Scientific and Policy Reports. Publications Office of the European Union. Luxemburg. 109 pp. 2012.

[18] Guéguen J, Charuau A. Essai de détermination du taux de survie des langoustines hors taille rejetées lors des opérations de pêche commerciale. ICES CM 1975/K:12. 1975.

[19] Charuau A, Morizur Y, Rivoalen JJ. Survival of discarded Nephrops norvegicus in the Bay of Biscay and in the Celtic Sea. ICES-CM-1982/B:13. 1982.

[20] Ulmestrand M, Valentinsson D, Sangster GI, Bova D, Kynoch RJ, Breen M, Graham GN, et al. Nephrops survival after escape from commercial fishing gear or discarded from deck. Fishing Technology and Fish Behaviour Working Group, La Coruña, Spain, 20-23 April 1998.

[21] Chapman CJ, Shelton PMJ, Shanks AM, Gaten E. Survival and growth of the Norway lobster Nephrops norvegicus in relation to light-induced eye damage. Marine Biology 2000; 136: 233-41.

[22] Harris RR, Andrews MB. Physiological changes in the Norway lobster Nephrops norvegicus (L.) escaping and discarded from commercial trawls on the West Coast of Scotland. Journal of Experimental Marine Biology and Ecology 2005; 320: 195-210.

[23] Ridgway ID, Taylor AC, Atkinson RJA, Chang ES, Neil DM. Impact of capture method and trawl duration on the health status of the Norway lobster, Nephrops norvegicus. Journal of Experimental Marine Biology and Ecology 2006; 339: 135-47.

[24] Méhault S, Morandau F, Fifas S. Discarded Nephrops survival after trawling. Working Document. Ifremer. $2011 . \quad$ Available at: https://w3.ifremer.fr/archimer/doc/00037/14829/12146.pdf.

[25] Raveau A, Macher C, Méhault S, Merzéréaud M, Le Grand C, Guyader O, Bertignac M, Fifas S, Guillen J. A bio-economic analysis of experimental selective devices in the Norway lobster (Nephrops norvegicus) fishery in the Bay of Biscay. Aquatic Living Resources 2012; 25: 215-29.

[26] Merzéréaud M, Macher C, Bertignac M, Frésard M, Le Grand C, Guyader O, Daures F, Fifas S. Description of the Impact Assessment bio-economic Model for fisheries management (IAM). Amure Electronic Publications, Working Papers Series D29-2011, 19 pp. 2011. Available at: http://www.umramure.fr/electro_doc_amure/D_29_2011.pdf

[27] Guillen J, Macher C, Merzéréaud M, Bertignac M, Fifas S, Guyader O. Estimating MSY and MEY in multi-species and multi-fleet fisheries: The Bay of Biscay mixed fishery. Marine Policy 2013; 40: 64-74.

[28] Sarkar D. Lattice: multivariate data visualization with R. Springer, New York. 2008.

[29] R Development Core Team. R: a language and environment for statistical computing. R Foundation for Statistical Computing, Vienna, Austria. 2011. Available at: http://www.R-project.org/

[30] STECF. Impact assessment of Bay of Biscay sole (STECF-11-01). JRC Scientific and Technical Reports. Publications Office of the European Union. Luxemburg. 38 pp. 2011.

[31] Mesnil B. When discards survive: accounting for survival of discards in fisheries assessments. Aquatic Living Resources 1996; 9: 209-15. 
[32] ICES. Report of the working group on the assessment of southern shelf stocks of hake, monk and megrim (WGHMM), 10 - 16 May 2012, Copenhagen, Denmark. ICES CM 2012/ACOM:11. 617 pp. 2012.

[33] Jennings S, Reynolds JD, Mills SC. Life history correlates of responses to fisheries exploitation. Proceedings of the Royal Society London Series B 1998; 265: 333-339.

[34] Law R. Fishing, selection, and phenotypic evolution. ICES Journal of Marine Science 2000; 57: 659-669.

[35] Kuparinen A, Merilä J. Detecting and managing fisheries-induced evolution. Trends in Ecology \& Evolution 2007; 22(12): 652-659.

[36] Groenewold S, Fonds M. Effects on benthic scavengers of discards and damaged benthos produced by the beam-trawl fishery in the southern North Sea. ICES Journal of Marine Science 2000; 57(5): 1395-1406.

[37] Tallack SML. Escape ring selectivity, bycatch, and discard survivability in the New England fishery for deep-water red crab, Chaceon quinquedens. ICES Journal of Marine Science 2007; 64 (8): 1579-1586.

[38] Di Nardo GT, De Martini EE, Haight WR. Estimates of lobster-handling mortality associated with the Northwestern Hawaiian Islands lobster-trap fishery. Fishery Bulletin - National Oceanic and Atmospheric Administration 2002; 100(1): 128-133.

[39] Broadhurst MK, Kennelly SJ, Isaksen B. Assessments of modified codends that reduce the by-catch of fish in two estuarine prawn-trawl fisheries in New South Wales, Australia. Fisheries Research 1996; 27: 89-111.

[40] Fonseca P, Campos A, Larsen RB, Borges TC, Erzini K. Using a modified Nordmøre grid for by-catch reduction in the Portuguese crustacean-trawl fishery. Fisheries Research 2005; 71: 223-39.

[41] Fonseca P, Campos A, Mendes B, Larsen RB. Potential use of a Nordmøre grid for by-catch reduction in a Portuguese bottom-trawl multispecies fishery. Fisheries Research 2005; 73: 49-66.

[42] Scott R, Sampson D. The sensitivity of long-term yield targets to changes in fishery age-selectivity. Marine Policy 2010; 35: 79-84.

[43] Cardinale M, Hjelm J. Size matters: short term loss and long term gain in a sizeselective fishery. Marine Policy 2012; 36: 903-6.

[44] Worm B, Hilborn R, Baum JK, Branch TA, Collie JS, Costello C, Fogarty MJ, Fulton EA, Hutchings JA, Jennings S, Jensen OP, Lotze HK, Mace PM, McClanahan TR, Minto C, Palumbi SR, Parma AM, Ricard D, Rosenberg AA, Watson R, Zeller D. Rebuilding global fisheries. Science 2009; 325: 578-85.

[45] FAO. The state of world fisheries and aquaculture. FAO Fisheries and Aquaculture Department, Rome, Italy. 209 pp. 2012.

[46] Kompas T. Fisheries management: economic efficiency and the concept of „Maximum Economic Yield". Australian Commodities 2005; 12: 152-60.

[47] Grafton RQ, Kompas T, Hilborn RW. Economics of overexploitation revisited. Science 2007; 318: 1601.

[48] Dichmont CM, Pascoe S, Kompas T, Punt A, Deng R. On implementing maximum economic yield in commercial fisheries. In: Proceedings of the National Academy of Sciences 2010; 107: 16-21.

[49] Asche F, Guillen J. The importance of fishing method, gear and origin: The Spanish hake market. Marine Policy 2012; 36: 365-9. 
Figures

Figure 1: Nephrops fishery in the Bay of Biscay

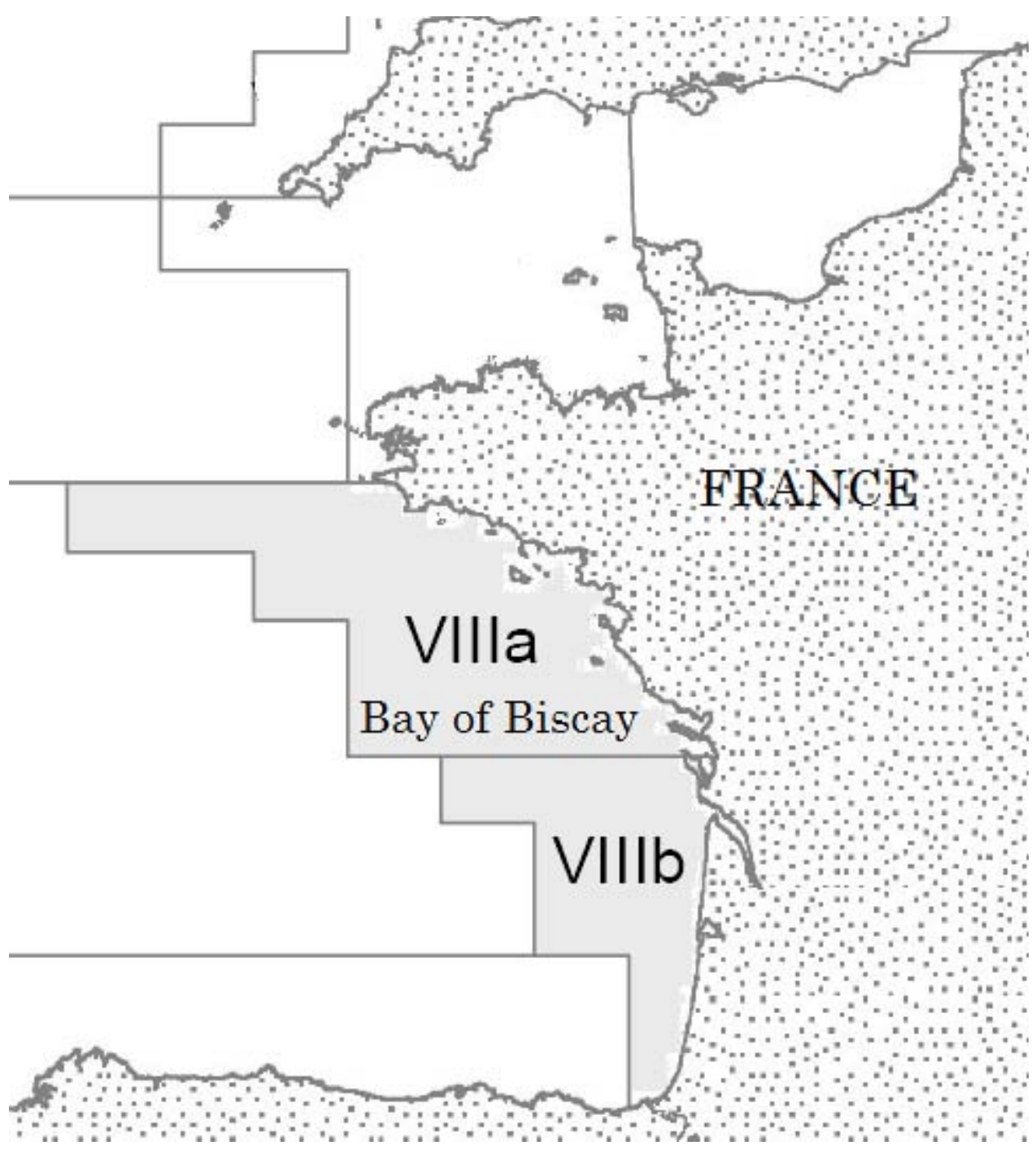


Figure 2a: Nephrops landings and catches as a function of effort without discard survival and MSY levels (scenarios A and B)

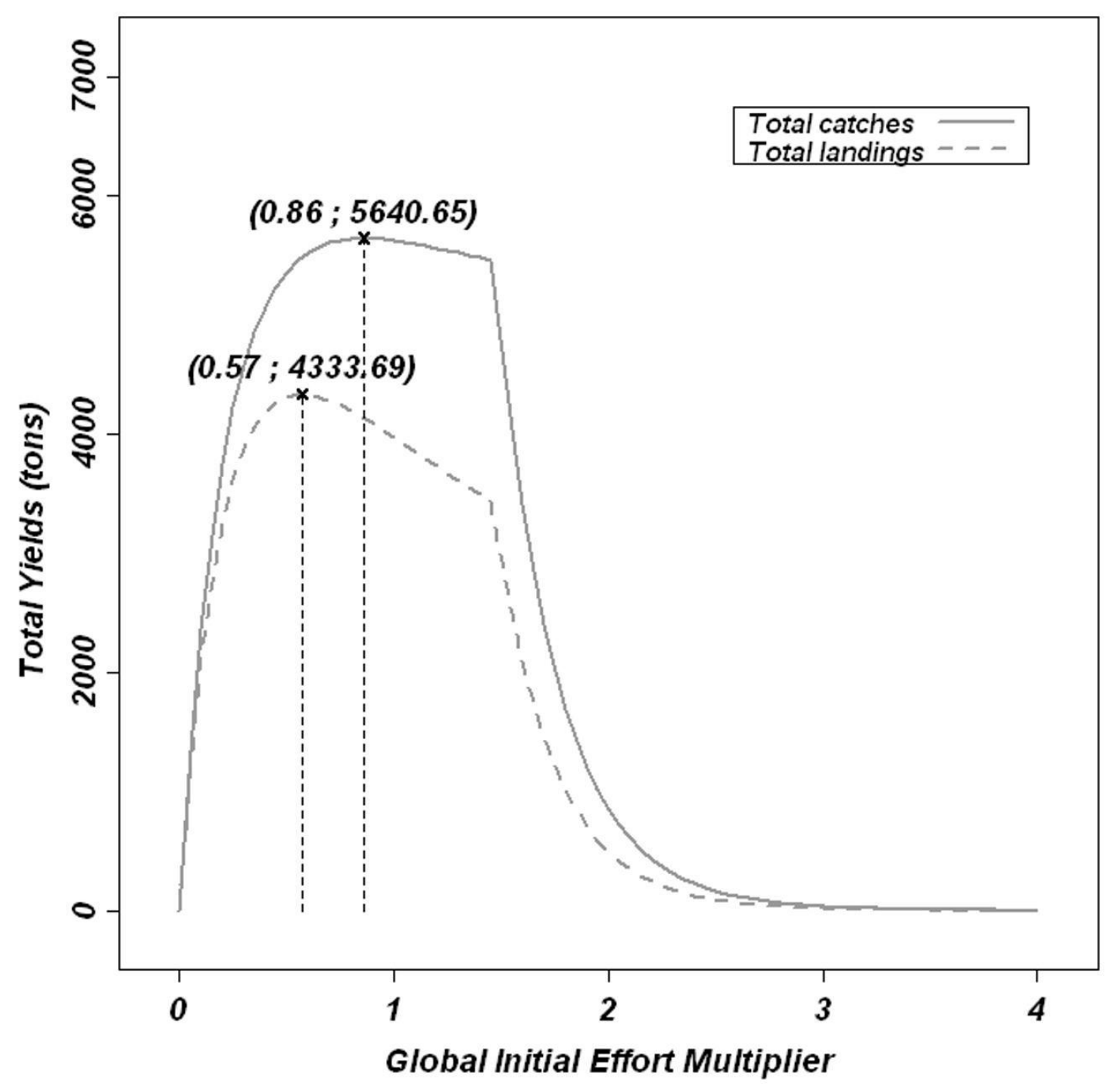


Figure 2b: Nephrops landings and catches as a function of effort with discard survival and MSY levels (scenarios C and D)

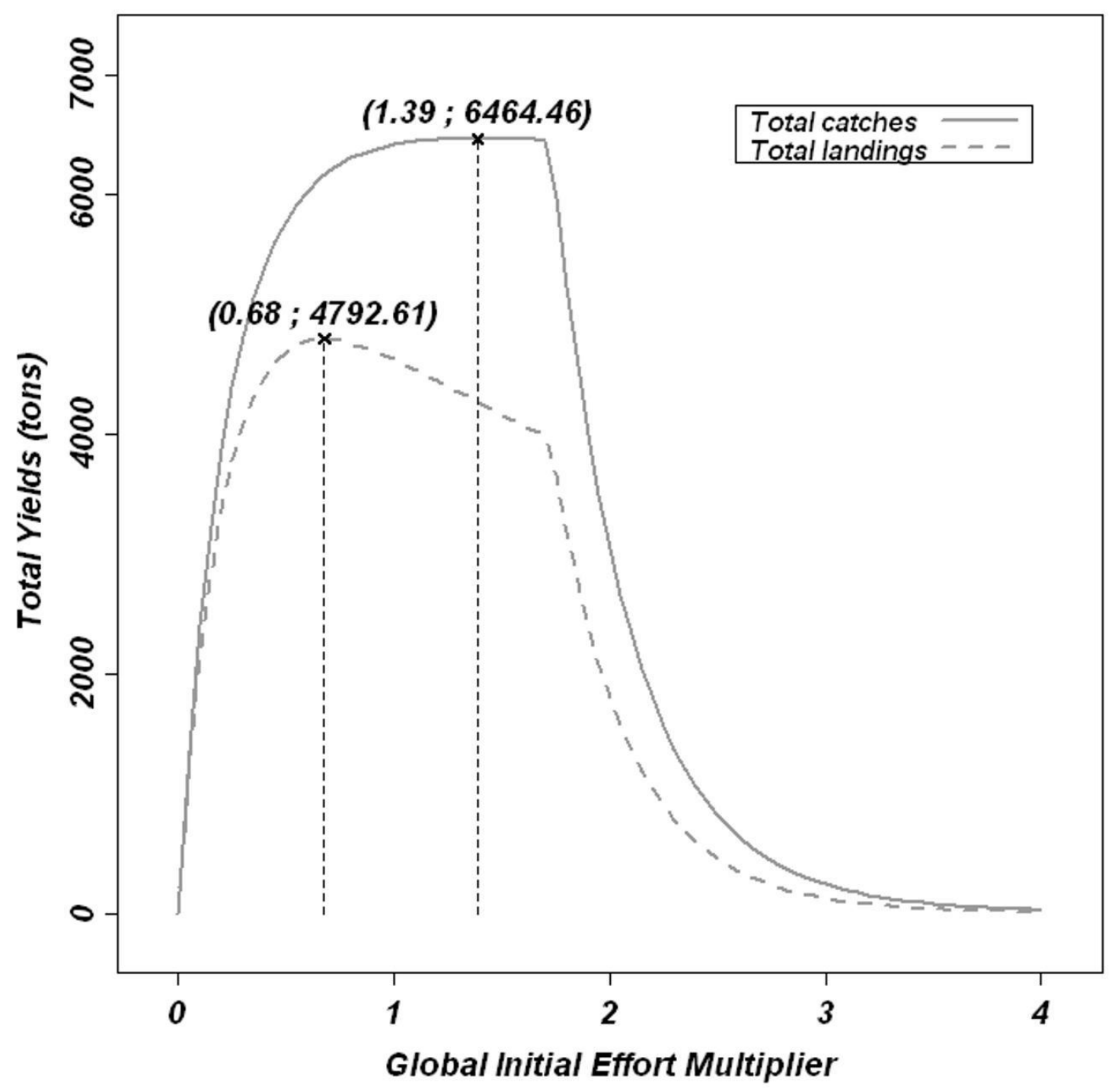


Figure 3a: Nephrops landings as a function of effort with and without discard survival and MSY levels (scenarios $A$ and $C$ )

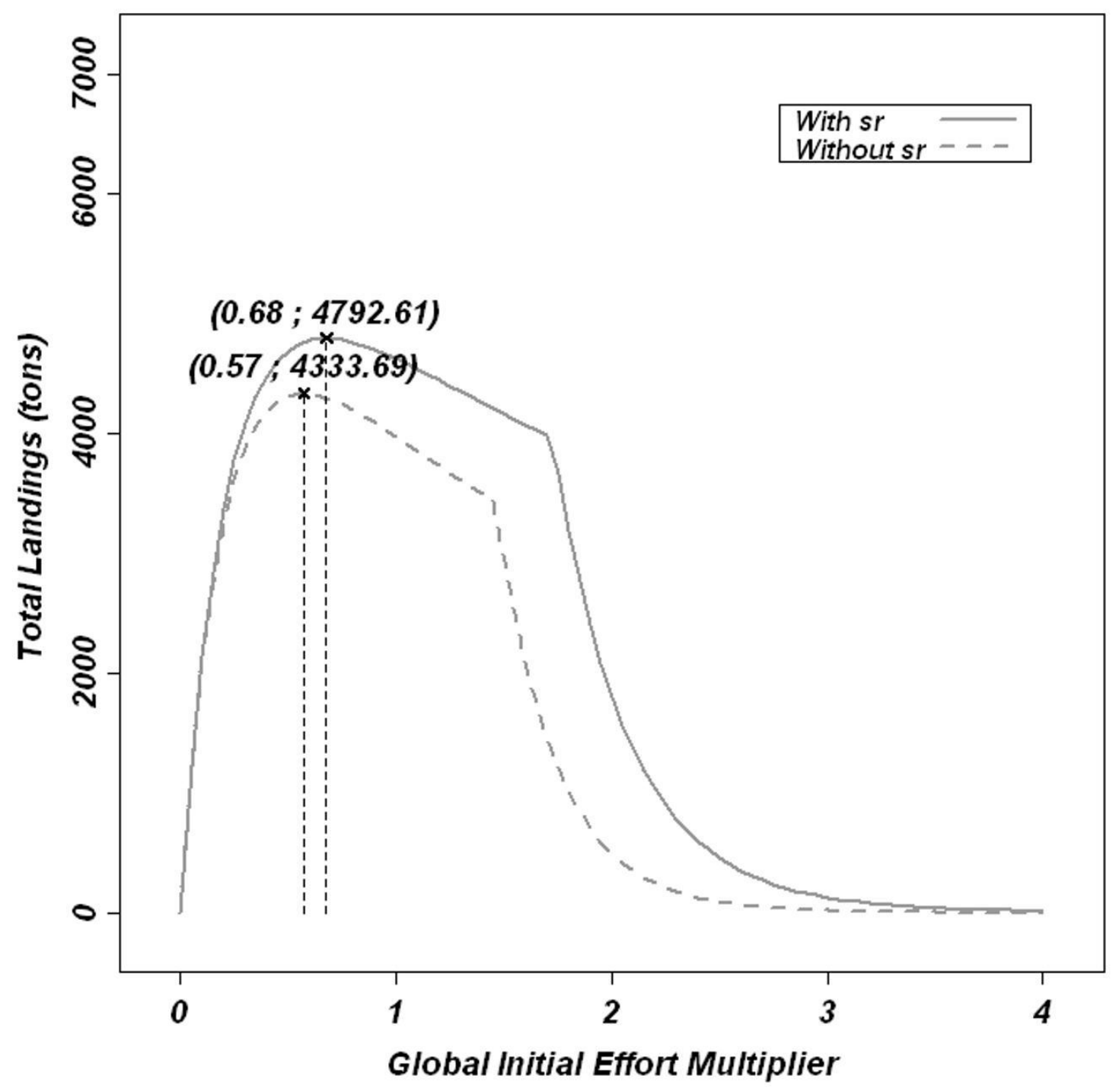


Figure 3b: Nephrops catches as a function of effort with and without discard survival and MSY levels (scenarios B and D)

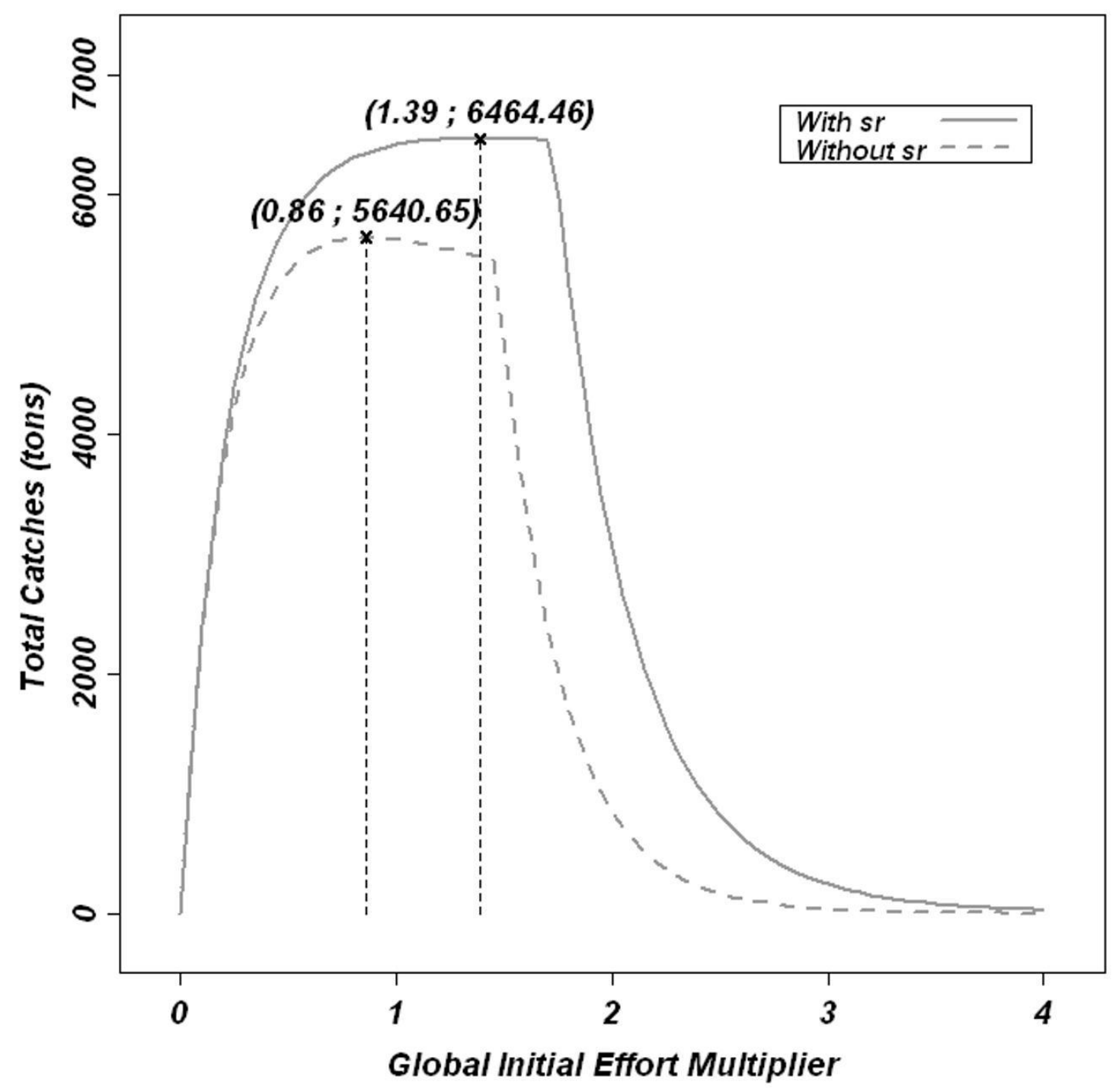


Figure 4: Maximum sustainable landings as a function of the fishing effort and survival rate. The colour scale shows the percentage of discards in the catches
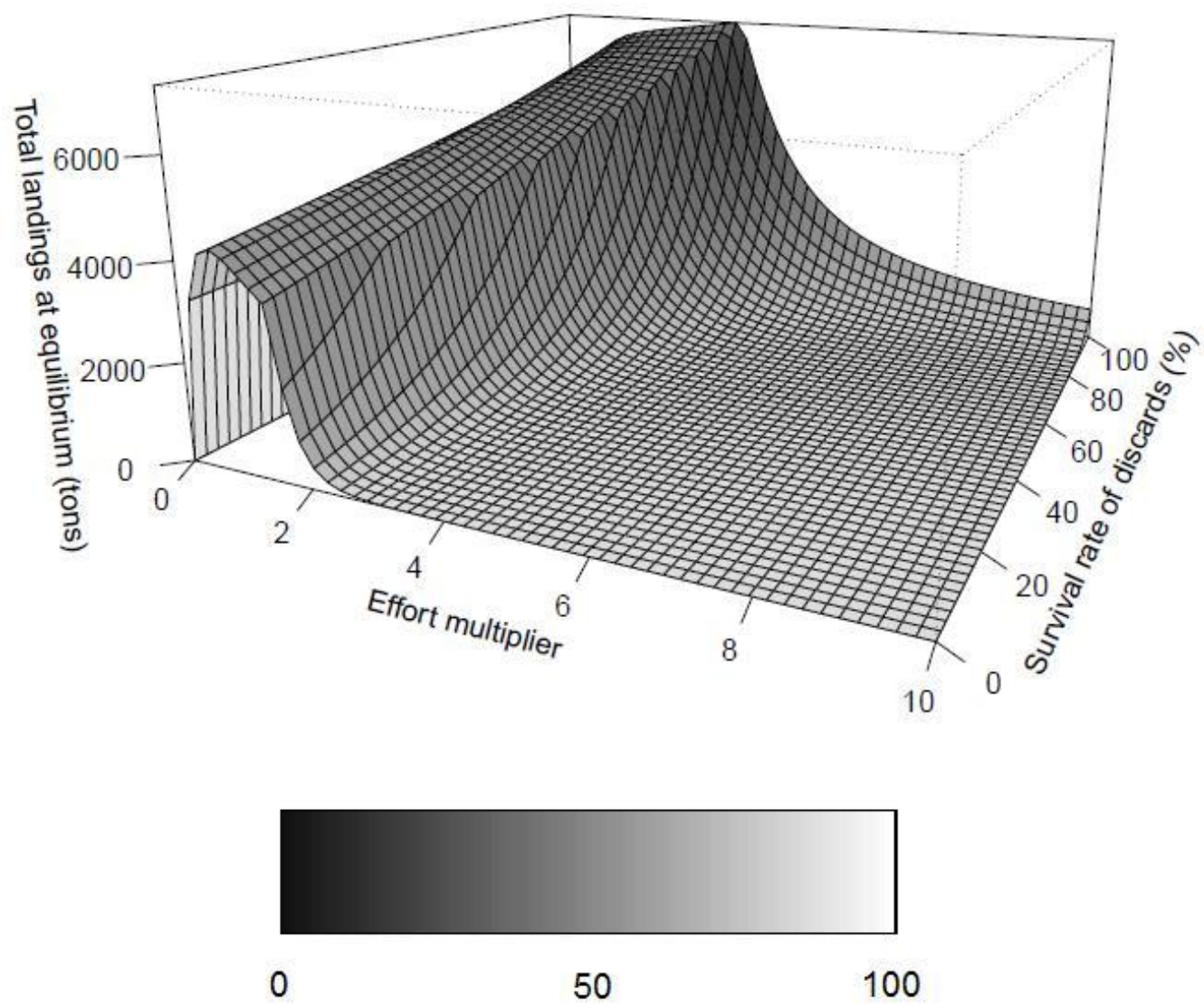


\section{Tables}

Table 1: Main data of the nephrops fishery in 2011 (ICES, 2012)

\begin{tabular}{lr} 
Biomass nephrops (Tonnes) & 16,666 \\
\hline F nephrops & 0.48 \\
\hline Catches nephrops (Tonnes) & 4,822 \\
\hline Discards nephrops (Tonnes) & 1,263 \\
\hline Landings nephrops (Tonnes) & 3,539 \\
\hline
\end{tabular}

Table 2: Nephrops stock data in 2011 (ICES, 2012)

\begin{tabular}{|c|c|c|c|c|c|c|c|c|}
\hline Age-class & $\begin{array}{l}\text { Stock size } \\
(' 000 \mathrm{~N})\end{array}$ & $\begin{array}{l}\text { Mean Weight } \\
\text { of biomass at } \\
\text { age }(\mathrm{gr})\left(w_{B}\right)\end{array}$ & $\begin{array}{l}\text { Fishing } \\
\text { mortality } \\
(F)\end{array}$ & $\begin{array}{l}\% \text { of } \\
\text { discards } \\
(d)\end{array}$ & $\begin{array}{l}\text { Mean Weight } \\
\text { of landings at } \\
\text { age }(\mathrm{gr})\left(w_{L}\right)\end{array}$ & $\begin{array}{l}\text { Mean Weight } \\
\text { of discards at } \\
\text { age }(\mathrm{gr})\left(w_{D}\right)\end{array}$ & $\begin{array}{l}\text { Natural } \\
\text { mortality }\end{array}$ & $\begin{array}{l}\text { Maturity } \\
\text { rate }(\%)\end{array}$ \\
\hline age 1 & 655,480 & 3.5 & 0.02 & 100.0 & 0.0 & 3.7 & 0.30 & 0 \\
\hline age 2 & 295,066 & 9.0 & 0.31 & 95.4 & 11.0 & 9.0 & 0.30 & 0 \\
\hline age 3 & 237,356 & 16.9 & 0.54 & 37.0 & 18.0 & 14.3 & 0.25 & 75 \\
\hline age 4 & 123,078 & 26.6 & 0.57 & 11.2 & 26.9 & 23.0 & 0.25 & 100 \\
\hline age 5 & 48,505 & 36.9 & 0.50 & 5.8 & 37.3 & 28.0 & 0.25 & 100 \\
\hline age 6 & 21,820 & 48.6 & 0.43 & 3.4 & 48.9 & 36.0 & 0.25 & 100 \\
\hline age 7 & 10,639 & 61.0 & 0.38 & 2.8 & 61.4 & 39.7 & 0.25 & 100 \\
\hline age 8 & 4,926 & 71.5 & 0.42 & 1.9 & 71.9 & 49.7 & 0.25 & 100 \\
\hline age $9+$ & 6,253 & 91.2 & 0.42 & 1.4 & 91.8 & 47.0 & 0.25 & 100 \\
\hline
\end{tabular}

Table 3: Summary of the scenarios tested

\begin{tabular}{|c|c|c|c|}
\hline & \multicolumn{2}{|c|}{ Maximising } \\
\hline & & Landings & Catches \\
\hline \multirow{2}{*}{ 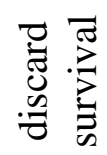 } & $0 \%$ & Scenario A & Scenario B \\
\hline & $30 \%$ & Scenario C & Scenario D \\
\hline
\end{tabular}


Table 4: Main results from the maximisation of catches and landings for the nephrops fishery

\begin{tabular}{|c|c|c|c|c|c|}
\hline Variables & $\begin{array}{l}\text { Current } \\
\text { Exploitation } \\
\text { Level }\end{array}$ & $\begin{array}{l}\text { Maximum } \\
\text { Landings } \\
\text { No survival } \\
\text { Scenario A } \\
\end{array}$ & $\begin{array}{l}\text { Maximum } \\
\text { Catches } \\
\text { No survival } \\
\text { Scenario B }\end{array}$ & $\begin{array}{l}\text { Maximum } \\
\text { Landings } \\
30 \% \text { survival } \\
\text { Scenario C }\end{array}$ & $\begin{array}{l}\text { Maximum } \\
\text { Catches } \\
30 \% \text { survival } \\
\text { Scenario D }\end{array}$ \\
\hline Effort multiplier & 1 & 0.57 & 0.86 & 0.68 & 1.39 \\
\hline F nephrops & 0.48 & 0.27 & 0.41 & 0.33 & 0.67 \\
\hline Catch nephrops (Tonnes) & 5,148 & 5,480 & 5,641 & 6,131 & 6,464 \\
\hline Landings nephrops (Tonnes) & 3,827 & 4,334 & 4,135 & 4,793 & 4,266 \\
\hline Discards nephrops (Tonnes) & 1,321 & 1,147 & 1,506 & 1,339 & 2,198 \\
\hline Biomass nephrops (Tonnes) & 16,665 & 28,478 & 20,852 & 27,769 & 16,239 \\
\hline $\begin{array}{l}\text { Average Weight of nephrops } \\
\text { Catches (gr.) }\end{array}$ & 19.5 & 23.8 & 20.5 & 23.2 & 17.6 \\
\hline $\begin{array}{l}\text { Average Weight of nephrops } \\
\text { Landings (gr.) }\end{array}$ & 27.2 & 29.9 & 26.1 & 28.9 & 22.5 \\
\hline $\begin{array}{l}\text { Average Weight of nephrops } \\
\text { Landings Biomass at Sea (gr.) }\end{array}$ & 11.9 & 15.8 & 12.8 & 15.4 & 10.7 \\
\hline
\end{tabular}

